\title{
Behavior and Characteristics of the Inhabitants of the State of Tocantins in Brazil with the Emergence of the New Coronavirus
}

\author{
Maykon Jhuly Martins de Paiva, Iangla Araújo de Melo Damasceno, Patricia Oliveira Vellano, Yurane da \\ Silva Barreira, Samara Borges de Azevedo, Avelina Alves Sales, Laryssa Magalhães da Silva, Gabriel \\ Epitácio Rodrigues Oliveira, Renata Ferreira Diogo, Nayara Sousa Tavares
}

\begin{abstract}
The contamination caused by the new coronavirus caused intense changes in the way of life of the population all over the world, threatening even the welfare of those who needed to restrict themselves. The objective of this work was to evaluate the behavior of the population of the state of Tocantins during the outbreak of COVID-19. It aims to evaluate aspects related to the behavior of the inhabitants of Tocantins during the COVID-19 pandemic. This is a cross-sectional study of the opinion poll type without identifying the participants, in compliance with CEP / CONEP resolution 510/16. The questionnaire was prepared on Google Forms, shared through social networks, with questions about the socioeconomic profile and factors associated with isolation. Hygiene habits were the most affected aspects among residents of Tocantins with $56.8 \%$ of participants. $63 \%$ of respondents believe that in Tocantins only a portion of the population is concerned with COVID-19. About isolation $35 \%$ answered that they are partially isolated. It is concluded that the behavior of the inhabitants of Tocantins in Brazil, changed significantly due to the pandemic. Characteristics such as gender, age and place of residence also influenced the perception and beliefs about the pandemic.
\end{abstract}

Index Terms - Behavior, Coronavirus, Pandemic

Maykon Jhuly Martins de Paiva, , Department of Pharmacy, Faculty of Palmas, Palmas, Tocantins, Brazil

Iangla Araújo de Melo Damasceno, Pharmacy Department of Centro Universitário Tocantinense Presidente Antônio Carlos, Araguaína, Tocantins, Brazil

Patricia Oliveira Vellano, Hospital Pharmacy Department, Araguaína Regional Hospital, Araguaína, Tocantins, Brazil

Yurane da Silva Barreira, Department of Pharmacy, Faculty of Palmas, Palmas, Tocantins, Brazil

Samara Borges de Azevedo, Department of Nutrition, Palmas School of Public Health, Palmas, Tocantins, Brazil

Avelina Alves Sales, Pharmacy Department of Centro Universitário Tocantinense Presidente Antônio Carlos, Araguaína, Tocantins, Brazil Laryssa Magalhães da Silva, Pharmacy Department of Centro Universitário Tocantinense Presidente Antônio Carlos, Araguaína, Tocantins, Brazil

Gabriel Epitácio Rodrigues Oliveira, Pharmacy Department of Centro Universitário Tocantinense Presidente Antônio Carlos, Araguaína, Tocantins, Brazil

Renata Ferreira Diogo, Pharmacy Department of Centro Universitário Tocantinense Presidente Antônio Carlos, Araguaína, Tocantins, Brazil.

Nayara Sousa Tavares, Pharmacy Department of Centro Universitário Tocantinense Presidente Antônio Carlos, Araguaína, Tocantins, Brazil.

\section{INTRODUCTION}

China was the country that firstly detected COVID-19, the outbkreak in cases happened in the city of Wuhan in Hubei province, where the first occurences were reported in December, 2019 [1].

The World Health Organization (WHO), identifying and registering a significant increase in the number of cases and deaths, and the presence of the virus in several countries around the world, declared that the occasion was an International Public Health Emergency in January 2020 [2], [3]. Initially, WHO had identified the new coronavirus as 2019-nCOV, with its high propagation capacity, the International Committee on Taxonomy of Viruses, classified it as SARS-CoV-2, which is known as the betacoronavirus, which has its identification genetic similarity with two other types of existing and already classified coronaviruses [4].

The Severe Acute Respiratory Syndrome of Coronavirus 1 (SARS-CoV-1) was first reported in November 2002 in the region of Guangdong Province, also in China, soon after it spread to countries on other continents such as Canada, Singapore and Vietnam [5].

SARS-CoV-2 is considered a zoonosis, and due to its ability to transmit to humans it has caused serious problems in Brazil and worldwide, its high transmissibility is mainly due to the contact with droplets expelled from the respiratory region of sick people who present symptoms, and also asymptomatic ones [6], [7].

The new pneumonia called worldwide "coronavirus" or COVID-19 has classic symptoms in patients, the main ones reported in the care centers are: cough, fever, dyspnea, pneumonia and diarrhea (Chen H, et al., 2020) . There are still controversies about the actual incubation period of the disease. However, researchers and doctors worldwide claim that the period varies from 2 to 14 days, averaging 4 to 6 days, however there are regions in the world where the period incubation period can reach up to 24 days [8].

Throughout Brazil, on May 20 the number of confirmed cases of the new coronavirus reached 271,885, with a total number of 17,983 deaths due to the disease. In the state of Tocantins, on the same date, the number of confirmed cases reached 1646, with a record of 38 deaths [9].

After the contamination dissipated all over Brazil and also through Tocantins, the federal, state, and municipal governments took several health measures in attempt to contain the spread of the new coronavirus, the main measure 
was the social distancing, a practice that became known for isolation at home [10].

WHO recommended collective isolation, with the purpose of postponing possible mass contamination of the population, thereby encouraging all countries and their respective states and provinces to adopt emergency measures in public health, especially by equipping health units such as hospitals, in addition to training professionals, considering that there is still no specific treatment, and a vaccine to combat the disease is not yet being offered [11].

In general, the isolation has caused changes in the Brazilian population, directly interfering in the daily routine, mainly due to the closing of schools and the adherence of companies to operating in the home-office system [12] In other countries, such as the United Kingdom and Italy, researches have shown that social isolation had difficulty acceptance, especially when the period extended for a long time, the lowest social class was the one that showed the greatest resistance in practicing isolation, however in these countries the population found it easier to perform personal hygiene practices [13].

In the meantime, the objective of this work was to evaluate, from the perception of the participants' residents, the aspects related to the behavior caused by the pandemic, in the residents of Tocantins.

Table 1. Source of information from respondents on the pandemic according to schooling.

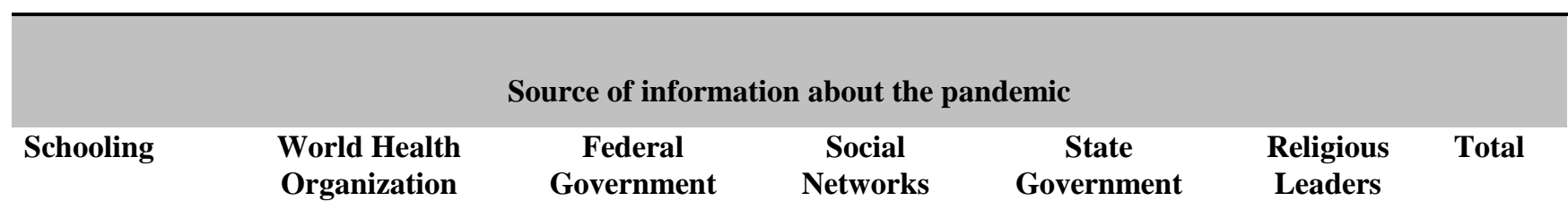

\begin{tabular}{|c|c|c|c|c|c|c|}
\hline Elementary & $39 \%$ & $20 \%$ & $13 \%$ & $20 \%$ & $8 \%$ & $100 \%$ \\
\hline High School & $54 \%$ & $29 \%$ & $7 \%$ & $7,5 \%$ & $2,5 \%$ & $100 \%$ \\
\hline College & $92,5 \%$ & $3,5 \%$ & $1,5 \%$ & $2,5 \%$ & $0 \%$ & $100 \%$ \\
\hline $\begin{array}{l}\text { Post } \\
\text { Graduation }\end{array}$ & $94 \%$ & $1,5 \% \%$ & $1 \%$ & $3,5 \%$ & $0 \%$ & $100 \%$ \\
\hline
\end{tabular}

Source: PAIVA, MJM., et al.,2020

\section{MATERIAL AND METHODS}

This is a cross-sectional study, using opinion poll without identifying the participants, in compliance with CEP / CONEP resolution 510/16, [10]. The research gathered data through the inhabitants of the state of Tocantins, Brazil. Who have some means of using the worldwide network of communication via computers, thus having a non-probabilistic sample result with convenience bias.

The questionnaire was prepared on Google Forms, shared through social networks, with questions about the socioeconomic profile and factors associated with isolation, between 20 and 22 May. A sample of 3,240 participants was obtained. The data were tabulated with the aid of Microsoft Excel software. In this study, absolute and relative frequencies were calculated using all variables.

\section{RESULTS}

In total, 3826 people answered the questionnaire, but after excluding incomplete answers, 3240 were considered valid. Of the total participants, $65 \%$ were female, $35 \%$ male. Regarding education, $69 \%$ of respondents had a college or graduate degree, while $21 \%$ high school and $10 \%$ elementary school.

Totalizing the number of people who participated in the survey, $56 \%$ said they were partially quarantined, which in this work is defined as leaving home for essential activities: buying food and medicines / emergency health services. Only $1.6 \%$ responded that they were totally inmates. Another $42.3 \%$ are not totally isolated and partially isolated.

Among the groups of people who are in total and partial isolation, $90.2 \%$ and $92.5 \%$, respectively, believe that the practice of isolating themselves at home has positive results for decreasing the number of cases and victims of the COVID-19 pandemic. About $8.2 \%$ of respondents still have doubts about the effectiveness of social isolation.

Regarding the possibility of contamination, $53.7 \%$ consider the risk of contagion by coronavirus in their area of activity as medium. 25.9\% consider the level high, and another $20.9 \%$ low. About contact with someone infected, $92.7 \%$ answered that they had no contact with people who tested positive for COVID-19.

Concerning the guidelines related to quarantine, $92.5 \%$ of the respondents who had higher education said that they follow the information provided by the World Health Organization, $29 \%$ of those with secondary education have 
the Fedreral Government as the main source of issues related to COVID-19 , $8 \%$ of respondents who have a fundamental level said they followed the information provided by religious leaders as can be seen in Table $\mathbf{1}$.

When asked how long they were willing to practice isolation, $61 \%$ who worked as a civil servant answered 2-3 months or as long as necessary, while workers in private companies, only $32.5 \%$ said they could stay away 2-3 months or whatever it takes to wait for the pandemic period to pass as shown in Table 2.

Table 2. Respondents who declare how long they are willing to practice isolation, according to main occupation

Amount of time people are willing to practice isolation.

\begin{tabular}{|c|c|c|c|}
\hline Main occupation & $\begin{array}{l}\text { Less than } \\
\text { a month }\end{array}$ & 1-2 months & $\begin{array}{l}\text { 2-3 months or the } \\
\text { necessary time }\end{array}$ \\
\hline
\end{tabular}

\begin{tabular}{ccccc} 
Civil Servant & $12 \%$ & $27 \%$ & $61 \%$ & $100 \%$ \\
Self-Employed & $48 \%$ & $37 \%$ & $15 \%$ & $100 \%$ \\
Employee of Private Company & $29 \%$ & $38,5 \%$ & $32,5 \%$ & $100 \%$ \\
Unemployed & & & $51 \%$ & $100 \%$ \\
Total & $17 \%$ & $32 \%$ & & $\mathbf{1 0 0 \%}$ \\
\hline
\end{tabular}

Source: PAIVA, MJM., et al.,2020

When asked about contamination by coronavirus in this country, $61.1 \%$ of the participants believe that pandemic in Brazil will be greater than in other countries whereas it has slowed down the. In the same way, $51.9 \%$ think that in Tocantins only a small portion of the population is concerned with the disease.

A total of $66.4 \%$ believe that people are not prepared to deal with personal hygiene in a pandemic situation. Another $43 \%$ believe that in the countryside cities, contamination of residents will be proportionally greater compared to the state capital Palmas.

\section{DISCUSSION}

It is almost unanimous worldwide that the use of social isolation was the crucial measure for flattening the curve of new cases of coronavirus widely, so the behavior of the population has a direct impact on the increase or decrease of cases and consequently in the number of deaths. Eastern countries such as South Korea and Japan have had positive results in reducing cases, thus decreasing the curve through measures that restrict the movement of people [12].

And the socioeconomic situation proved to be a decisive aspect for the population to stay or leave home in this study, as can be seen in Table 2, most civil servants who tend to have greater financial stability, through fixed remuneration and public tender (67\%) said from 2 to 3 months in isolation or as long as necessary until it is considered safe to return to normal routine [10]

In the same vein, the scenario is different for respondents who are self-employed, only $15 \%$ said they were prepared to spend 2 to 3 months in isolation, so income is an important factor to contain the spread of the coronavirus in
Tocantins and also in Brazil, since the pandemic also caused an increase in the unemployment rate [12]

It is important to emphasize that the joining to partial or total isolation may be related to the fear that the population has in situations such as unexpected and unknown diseases, which could cause material and personal losses, and those related to health are the most reported when is related to contamination by viral diseases [14].

The level of education is another factor that draws attention mainly related to information, $13 \%$ of respondents who have elementary education responded to having social media as an information source, which can often generate data conflict and even the dissemination of information such as the distribution of indications of drugs that promise a cure for the new coronavirus, which can also be considered an important factor for the spread of infectious viral diseases [15]. Or even the appearance of other diseases, such as drug intoxications [16].

Regarding hygiene in this study, $66.4 \%$ of respondents said they believe that the community is not prepared to deal with hygiene, a factor that draws attention is mainly the simple fact of washing hands. One hypothesis is that an important portion of the population does not know the correct hygiene technique, studies have shown that within the own hospital units, health professionals and administrative technicians have doubts about the correct procedure, which also favors the spread of infections at the hospital level [17].

Another aspect is the belief related to contamination in Tocantins, the majority of residents $(43 \%)$ believe that in the countryside cities the contamination is greater, a factor that could justify this thought would be that in these cities, people traditionally visit the homes of relatives and neighbors, thus limiting the isolation and the restriction of contagion, the countryside life tends to be more peaceful and 
consequently forms a network of contacts with greater frequency and ease [10].

It is important to highlight the limitations in this study, considering that the data presented and discussed in this study, despite being collected in several cities in Tocantins and in different segments of the population of the state, it possesses as a main limitation the convenience of the sample, which was subject to bias of selection, however it is representative of the sampled universe.

\section{CONCLUSION}

The data from this study revealed a significant change in the behavior of the inhabitants of Tocantins, with the majority believing that social isolation is important to contain the spread of COVID-19 and mainly to reduce the number of deaths. However, it is possible to observe that socioeconomic factors directly reflect on the results of hygiene, knowledge and the adoption of restrictive measures by the population.

The pandemic has undoubtedly brought social and psychological effects to the population, increasing cases of anxiety and situations of vulnerability such as becoming ill, going to hospitals, losing jobs, or being excluded from the city due to contracting the disease.

Therefore, the interdisciplinary work of health professionals is necessary mainly for the most vulnerable population not to be affected by such disorders. As a result, interventions through public policies aimed at the quality of life and well-being of the population need to be intensified in this new way of life after the pandemic.

\section{ACKNOWLEDGMENT}

We appreciate the team of the Pharmacy Department of Palmas College and the Pharmacy Department of the Tocantinense University Center President Antônio Carlos, who contributed decisively in the realization of this study in the data collection phase.

\section{REFERENCES}

[1]. Onyeaka H.K, et al. The unaddressed 16 Spectorf behavioral behavior during a coronavirus pandemic. Cureus., 2020; 12(3): e7351.

[2]. Gonçalves F.N.R, et al. Epidemiologia do Surto de doença por Coronavírus (Covid-19). DESAFIOS - Revista Interdisciplinar da Universidade Federal do Tocantins, 2020; 7(Especial-3): 18-25.

[3]. Chan J, et al. A familial cluster of pneumonia associated with the 2019 novel coronavirus indicating person-to-person transmission: a study of a family cluster. The Lancet, 2020; 395(10223): 514-523.

[4]. Zhou P, et al. A pneumonia outbreak associated with a new coronavirus of probable bat origin. Nature, 2020; 579(7798): $270-273$.

[5]. Hui D.S. Epidemic and emerging Coronaviruses (Severe Acute Respiratory Syndrome and Middle East Respiratory Syndrome). Clin Chest Med., 2017; 38(1): 71-86.

[6]. Silva Fe. SARS-COV-2 - Aspectos Relacionados A Biologia, Propagação E Transmissão Da Doença Emergente Covid-19. DESAFIOS Revista Interdisciplinar da Universidade Federal do Tocantins, 2020; 7 (Especial-3): 9-17.
[7]. WHO. (WORLD HEALTH ORGANIZATION) 2020. World Health Organization. Q\&A on coronavirus (COVID-19) Disponível: https://www.who.int/csr/sars/en/WHOconsensus.pdf Acesso em 15 de maio de 2020.

[8]. Bai Y. Presumed asymptomatic carrier transmission of COVID -19. JAMA, 2020; 323(14):1406-1407

[9]. MINISTÉRIO DA SAUDE DO BRASIL. 2020. Painel Coronavírus. Disponível em: https://covid.saude.gov.br/ Acesso: em 20 de Maio de 2020.

[10]. Bezerra A.S, et al. Fatores associados ao comportamento da população durante o isolamento social na pandemia de COVID-19. Cien. Saude Colet. 2020; 69 .

[11]. Monte L.M.D, Complicações atípicas e características clínico-epidemiológicas do COVID-19: uma revisão integrativa. REAS. 2020;(46):e3699.

[12]. Lima D.L.F, et al. COVID-19 no estado do Ceará, Brasil: comportamentos e crenças na chegada da pandemia. Ciência \& Saúde Coletiva, 2020; 20: 1575-1586.

[13]. Atchimson C, et al. Perceptions and behavioural responses of the general public during the COVID-19 pandemic: A cross-sectional survey of UK Adults. medRxiv. 2020.

[14].Camargo $\mathrm{Bv}$; Bertoldo $\mathrm{Rb}$. Comparação da vulnerabilidade de estudantes da escola pública e particular em relação ao HIV. Estud. psicol. (Campinas), 2006; 23(4): 369-379.

[15].Lemos Drq, et al. Fatores de risco associados à gravidade e óbitos por influenza durante a Pandemia de Influenza A (H1N1) 2009 em região tropical/semi-árida do Brasil. J Health Biol Sci. 2015; 3(2):77-85.

[16]. Margonato $\mathrm{Fb}$, et al. Determinantes nas intoxicações medicamentosas agudas na zona urbana de um município do Sul do Brasil. Cad. Saúde Pública, 2008; 24(2): 333-341.

[17]. Turrini Rnt. Percepção das enfermeiras sobre fatores de risco para a infecção hospitalar. Rev. esc. enferm. USP, 2000; 34(2):174-184.

[18]. Chen h, et al. Clinical characteristics and intrauterine vertical transmission potential of COVID-19 infection in nine pregnant women: a retrospective review of medical records. Lancet, 2020; 395: 809-815.

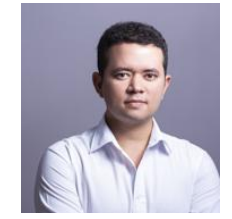

Maykon Jhuly Martins de Paiva, He is currently an adjunct professor and researcher at the Faculty of Palmas, responsible for the Pharmacy department.

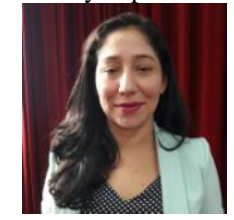
an adjunct professor and researcher at the Centro Universitário Tocantinense Presidente Antônio Carlos , responsible for the Pharmacy department.

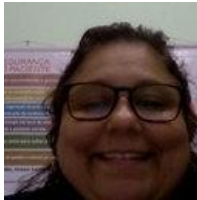

Patrícia Oliveira Vellano, Hospital Pharmacist, responsible for the hospital infection control sector, university professor for 15 years. 